\title{
Ex-situ Seed Conservation of Endangered Key Tree Cactus (Pilosocereus robinii)
}

Ana Salazar*, Joyce Maschinski and Devon Powell

Fairchild Tropical Botanic Garden, Kushlan Tropical Science Institute, Coral Gables, Florida, USA

\begin{abstract}
Ex-situ seed collections are fundamental to the conservation of threatened and endangered plant species. We tested whether or not seeds of the U.S. endangered tree cactus, Pilosocereus robinii, withstand orthodox storage conditions of low humidity $(25 \% \mathrm{RH})$ and freezing temperatures $\left(-20^{\circ} \mathrm{C}\right)$. Mean final germination of fresh seeds and seeds stored under low humidity and low temperature for 1 and 28 weeks ranged from 92 to $96 \%$. Mean final germination did not differ significantly across storage conditions. Seed germination rate exhibited small, but significant differences across storage conditions. Seeds stored under dry conditions of low humidity and ambient temperature germinated significantly faster than dry-stored seeds maintained at freezing temperatures and fresh seeds. Because orthodox methods of drying and freezing can be used to store seeds of Pilosocereus robinii, ex-situ seed banking can effectively assist the conservation and regeneration of this endangered species.
\end{abstract}

Keywords: Genetic diversity; Orthodox storage; Seed germination; Seed storage

\section{Introduction}

Ex-situ seed collections are fundamental to the conservation and habitat restoration of plant species, particularly those at risk of extinction [1-3]. Ex-situ seed collections of threatened and endangered plant species are becoming crucial to assist plant reintroduction and restoration programs as disturbance intensity and frequency caused by global warming and human-induced land use changes affect populations in the wild [4]. Ex-situ conservation of seeds represents an efficient and cost-effective method of conserving the variation within and among individual flowering plant species [5]. Ex-situ seed conservation provides broader genetic representation than would be possible with living collections [6] because propagation by seeds maintains the genetic diversity of plant populations and species $[7,8]$. Ex-situ seed bank conservation also provides long-term insurance against species or genotype loss until actual or potential threats in wild populations can be removed [6].

Many species have seeds that can be stored for long periods at low moisture contents (3-7\%, dry weight basis) and low temperature $\left(-18^{\circ} \mathrm{C}\right)$ without damage. These seeds are referred as orthodox seeds [9]. Ex-situ seed storage has been used successfully for the longterm maintenance of viable collections of crop and wild species [8] and more recently threatened species [6]. Determining seed storage behavior of rare wild species is crucial, particularly under the current global warming scenarios [10]. However, little is known about seed germination and dormancy of many rare and threatened species [11]. Thus, studies of optimal seed storage conditions are required to support conservation and reintroduction programs of plant species that are at risk of extinction [12].

Populations of the endangered Key tree cactus (Pilosocereus robinii) have largely declined in the last decade as a result of increases in soil salinity [13] and due to high intensity and frequency of recent hurricane storm surges [14]. Hurricanes have particularly affected populations that reside below $1.4 \mathrm{~m}$ elevation because heavy rainfall and storm surges highly affect this species, which prefers lightly shaded, welldrained upland sites with little or no soil development [15]. Increased rate of sea level rise may exacerbate storm surge of low-lying coastal habitats and may cause saltwater to infiltrate the ground water and raise soil salinity [13]. Physiological stress, mortality or limited recruitment may result if soil salinity increases beyond the tolerance levels of Pilosocereus robinii [13]. Habitat destruction and alteration have further reduced the population size of Pilosocereus robinii. Therefore, there is an immediate need to secure germplasm of this rare species at an ex-situ location [13]. Whether or not seeds of Pilosocereus robinii could be stored under low humidity and low temperature conditions without losing their viability was not known. In this study we tested the tolerance of Pilosocereus robinii seeds to orthodox storage conditions and specifically addressed the following question: Do Pilosocereus robinii seeds withstand dry storage conditions under low humidity $(25 \% \mathrm{RH})$ and low temperature $\left(-20^{\circ} \mathrm{C}\right)$ without losing their viability.

\section{Methods}

\section{Study species}

The federal and state listed endangered Pilosocereus robinii occurs in the Florida Keys and Cuba (Figure 1). This columnar cactus grows up to $10 \mathrm{~m}$ and predominantly reproduces vegetative when windthrown branches produce roots and give rise to new upright stems [13]. In contrast, seed production and dispersal are very limited; from 2007-2010 only four plants in the Florida Keys produced fruits [13]. Fruits are reddish $3.5 \mathrm{~cm}$ in diameter, and dispersed by unknown frugivores [16]. Fruits produce an average of 536 black and shiny small seeds of about $2.5 \mathrm{~mm}$ in length $[17,18]$. Pilosocereus robinii grows on limestone soil overtopped with organic soil layer [19] at $0.26-1.71 \mathrm{~m}$ elevations in hardwood hammocks [20]. Since the early 1900s habitat destruction and habitat alteration have contributed to the endangered status of the species. Great threats to the few individuals, approximately

*Corresponding author: Ana Salazar, Fairchild Tropical Botanic Garden, Kushlan Tropical Science Institute, Coral Gables, Florida, 33156, USA, E-mail: asalparra@gmail.com

Received August 14, 2013; Accepted September 16, 2013; Published September 25,2013

Citation: Salazar A, Maschinski J, Powell D (2013) Ex-situ Seed Conservation of Endangered Key Tree Cactus (Pilosocereus robinii). J Biodivers Endanger

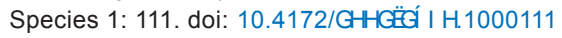

Copyright: ( 2013 Salazar A, et al. This is an open-access article distributed under the terms of the Creative Commons Attribution License, which permits unrestricted use, distribution, and reproduction in any medium, provided the original author and source are credited. 


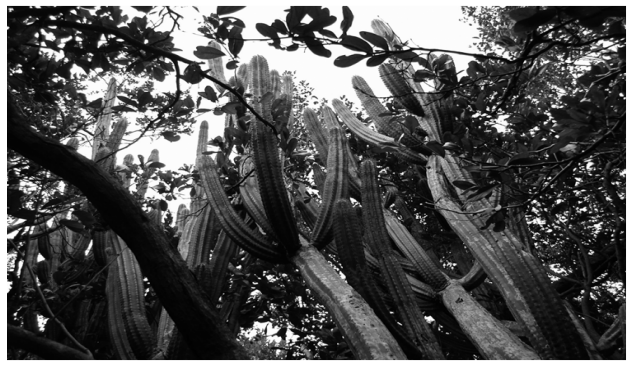

Figure 1: Trees of Pilosocereus robinii growing in the Florida Keys. These are estimated to be 5-6 $\mathrm{m}$ tall.

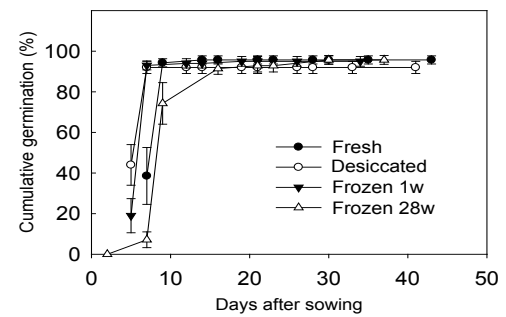

Figure 2: Cumulative Germination Curves (\%) of Pilosocereus robinii seeds stored under four different experimental conditions: Fresh seeds dried unde ambient conditions $\left(21^{\circ} \mathrm{C}, 50 \% \mathrm{RH}\right)$, Desiccated (seeds desiccated at $21^{\circ} \mathrm{C}$ $25 \% \mathrm{RH}$ for three days), Frozen $1 \mathrm{w}$ (seeds desiccated at $21^{\circ} \mathrm{C}, 25 \% \mathrm{RH}$ for three days and kept frozen at $20^{\circ} \mathrm{C}$ for 1 week), and Frozen $28 \mathrm{w}$ (seeds desiccated at $21^{\circ} \mathrm{C}, 25 \% \mathrm{RH}$ for three days and kept frozen at $-20^{\circ} \mathrm{C}$ for 28 weeks). Lines are means $+S E(n=10$ for conditions 2 and $3, n=7$ for conditions 1 and 4).

3,360 , growing in eight widely separated populations with low sexual reproduction triggered the species' listing as endangered under the US Endangered Species Act in 1984 [15]. Early surveys for Pilosocereus robinii found that the species had been extirpated from at least three Florida Keys, but eight extant populations existed on 5 islands and one population of P. bahamensis, Byles and Rowley [21] was identified on Key Largo. In 2013, there were six populations comprising approximately 350 stems in the Florida Keys (unpublished data). Urban development continues to be the worst threat to this species. Although fire is rare in hardwood hammocks, it has the potential to devastate a population [22].

\section{Seed orthodox storage}

To determine whether Pilosocereus robinii seeds withstand storage under low humidity and low temperatures we subjected the seeds to desiccation and freezing and conducted germination trials. We collected 340 seeds from a single parent plant that produced seeds in the ex-situ nursery collection at Fairchild Tropical Botanic Garden. After cleaning, we stored the seeds under laboratory dry-storage conditions in paper envelopes under ambient conditions $\left(21-23^{\circ} \mathrm{C}\right.$, $50 \% \mathrm{RH}$ ) for approximately 11 days until the beginning of germination trials. We conducted germination trials for seeds in each of four storage conditions: 1) fresh seeds under ambient conditions, 2) seeds desiccated at $21-23^{\circ} \mathrm{C}, 25 \% \mathrm{RH}$ for 3 days, 3 ) seeds desiccated at 21 $23^{\circ} \mathrm{C}, 25 \% \mathrm{RH}$ for 3 days and frozen at $-20^{\circ} \mathrm{C}$ for one week and 4 ) seeds desiccated at $21-23^{\circ} \mathrm{C}, 25 \% \mathrm{RH}$ for 3 days and frozen at $-20^{\circ} \mathrm{C}$ for 28 weeks. Seven replicates of 10 seeds each were used for treatments 1 and 4. Ten replicates of 10 seeds were used for treatments 2 and 3 . We dried seeds at $25 \% \mathrm{RH}$ over $\mathrm{MgCl}$ salts for three days inside a desiccators jar. After desiccation, we sealed seeds in foil packs and froze them at $-20^{\circ} \mathrm{C}$ for one week or 28 weeks. Because scarification with sulfuric acid has been shown to be an effective method to break dormancy of Harrisia fragrans (Cactaceae) seeds [23] after the treatments we soaked the seeds in $1 \mathrm{~N}$ sulfuric acid $\left(\mathrm{H}_{2} \mathrm{SO}_{4}\right)$ for one minute, rinsed them twice with tap water, and then soaked them in tap water for 15 minutes. We sowed the scarified seeds in Petri dishes on filter paper and dampened with plant preservative mixture water $\left(\right.$ Caisson $\left.{ }^{\circledR}\right)$. We placed the Petri dishes on germination racks at $25^{\circ} \mathrm{C}, 50 \%$ relative humidity and $24 \mathrm{~h}$ photoperiod. We recorded germination radical protrusion two to times per week up to 43 days, when no more germination was observed, and watered the seeds as needed.

\section{Data analysis}

For each replicate, we calculated final germination percentage, speed of germination $\left(\mathrm{R}^{50}\right)$ and Mean Germination Time (MGT). $\mathrm{R}^{50}$ was calculated as the number of days until $50 \%$ of the seeds had germinated. MGT was calculated as:

$$
M G T=\frac{\sum_{i=1}^{k} n i t i}{\sum_{i=1}^{k} n i}
$$

where $n i$ is the number of seeds germinated in the time $i$, $t i$ is the time from the start of the experiment to the $i^{\text {th }}$ observation, and $\mathrm{k}$ is the time of last germination [24]. Differences in the final percentage of seed germination, $\mathrm{R}^{50}$, and mean germination time were examined with One-way ANOVA tests with unequal samples. After each test we used Tukey's HSD post-hoc tests to analyze multiple comparisons of means. Analyses were performed in SPSS 2010.

\section{Results}

Germination of fresh seeds and seeds stored under low humidity and low temperatures began within 5 and 9 days after sowing Figure 2. Mean final germination of fresh seeds was $96 \%$. Similarly, mean final germination of seeds stored under low humidity and low temperatures ranged from $92 \%$ desiccated seeds at $25 \% \mathrm{RH}$ at $21-23^{\circ} \mathrm{C}$ for 3 days to $96 \%$ desiccated seeds at $25 \% \mathrm{RH}$ at $21-23^{\circ} \mathrm{C}$ for 3 days and kept frozen at $-20^{\circ} \mathrm{C}$ for 28 weeks, Figure 2. Final percent seed germination did not differ significantly across storage conditions $\left(\mathrm{F}_{3,30}=0.5, \mathrm{P}=0.65\right.$, Figure 2). Germination rate, estimated as the number of days to reach $50 \%$ of the final germination $\left(\mathrm{R}^{50}\right)$, ranged from 5 to 9 days and differed significantly among seed storage conditions $\left(\mathrm{F}_{3,30}=23.04, \mathrm{P}<0.0001\right.$, Figure 3A). Seeds stored under dry conditions of low humidity $(25 \% \mathrm{RH})$ and low temperature $\left(-20^{\circ} \mathrm{C}\right)$ for one week reached $50 \%$ of their germination significantly faster than either fresh seeds stored under ambient conditions $\left(21-23^{\circ} \mathrm{C}\right.$ and $\left.50 \% \mathrm{RH}\right)$ or seeds desiccated and frozen for 28 weeks Figure $3 \mathrm{~A}$.

Mean Germination Time (MGT) ranged from 0.05 to 2.6 days and also differed significantly among storage conditions $\left(\mathrm{F}_{3,30}=10.39\right.$, $\mathrm{P}<0.0001$, Figure $3 \mathrm{~B})$. Seeds desiccated at $25 \% \mathrm{RH}$ at $21-23^{\circ} \mathrm{C}$ for 3 days germinated faster than fresh or desiccated and frozen seeds. Mean germination time, however did not differ significantly among fresh seeds and dry-stored seeds stored at low temperatures Figure 3B.

\section{Discussion}

Our results indicate that Pilosocereus robinii seeds can be stored at low relative humidity and freezing temperatures without losing their viability. Our results agree with those of Goodman et al. [23] who found that seeds of Harrisia fragrans, a globally endangered cactus, can withstand orthodox storage conditions. Our results also agree with studies on cactus species from coastal and arid regions of Brazil, which 


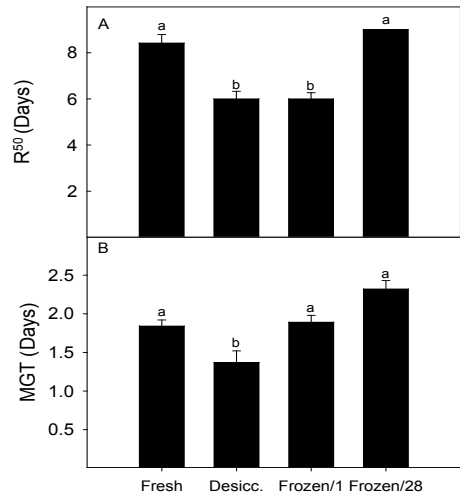

Figure 3: $(A)$ Number of days to reach $50 \%$ Germination $\left(R^{50}\right)$ and $(B)$ Mean Germination Time (MGT) in days of Pilosocereus robinii seeds stored under four different experimental conditions: Fresh (seeds dried under ambient conditions of $21^{\circ} \mathrm{C}, 50 \% \mathrm{RH}$ for 11 days), Desicc. (Seeds desiccated at $25 \%$ $\mathrm{RH}$ for three days), Frozen/1 (seeds desiccated at $25 \% \mathrm{RH}$ for three days and kept frozen at $-20^{\circ} \mathrm{C}$ for 1 week), and Frozen $/ 28$ (seeds desiccated at $25 \% \mathrm{RH}$ for three days and kept frozen at $-20^{\circ} \mathrm{C}$ for 28 weeks). Bars are means $+\mathrm{SE}$ ( $n=10$ for conditions 2 and $3, n=7$ for conditions 1 and 4 ). Bars topped with the same letter do not differ significantly $(P<0.05)$ according to Tukey HSD posthoc test.

exhibit orthodox seed behavior [25]. In our study, seed germination rate exhibited small, but significant differences across storage conditions. Desiccated seeds stored at room temperature and desiccated seeds stored under low temperature for one week germinated significantly faster than recently collected fresh seeds stored at room temperature or desiccated seeds stored under low temperature for 28 weeks. Differences in germination rates between fresh and stored seeds have been observed in other cactus species. Seeds of Opuntia rastrera, for example exhibited high germination rates as they aged [26]. Potter et al. [27] also found that long dry-stored seeds of Opuntia lindheimeri and Opuntia spp. had higher germination rates than recently collected seeds. De la Barrera and Nobel [28] found that seeds of Stenocereus queretaroensis reached their maximum germination after 12 to 28 months of dry-storage. Future studies should further assess the effect of drying and freezing on the germination rate of seeds collected from several parental plants as well as determine if dry and cold stored seeds of Pilosocereus robinii remain alive for periods longer than 28 weeks.

The ability of Pilosocereus robinii seeds to withstand drying and freezing offers not only a viable option for the long term seed conservation of this species in ex-situ conditions but also suggests that seeds may persist in natural soil seed banks for relatively long periods as many cacti species that have dormancy have been documented to form at least a short-term seed bank if they are able to avoid predation [7]. Seeds of Stenocereus griseus from a semi-arid area of Venezuela remained viable in the soil for 4 months [29] and germination of stored seeds of Opuntia rastrera seeds was higher than recently collected seeds [26] indicating that these species could form soil seed banks. Seed burial experiments should therefore be conducted to determine the ability of Pilosocereus robinii seeds to form persistent soil seed banks in situ. Having a persistent seed bank is particularly important for plant recruitment in disturbance-prone South Florida ecosystems where major hurricane disturbances are frequent. Studies in South Florida have found that some rare plant species do regenerate from the soil seed bank in historical sites following hurricanes [30]. Protecting sites where this endangered species has historically been found is critical, given that populations believed to be extirpated may in fact still exist in a persistent soil seed bank.

Seed longevity is a valuable attribute because it simplifies germplasm conservation through seed storage [31]. Long-term storage of Pilosocereus robinii seeds could help preserve the genetic diversity of the species. Stored seeds also may be used to restore declining natural populations of this rare species as has been done in other endangered plants [10]. Future studies, however are necessary to determine if dry and cold-stored seeds of Pilosocereus robinii remain alive for periods longer than 28 weeks and to determine the lifespan of different seed accessions stored in dry and cold conditions.

In conclusion, this study shows that seeds of the endangered Key tree cactus can withstand orthodox storage conditions without losing their viability. Seeds stored under low humidity and low temperatures reached germination values higher than $90 \%$ within 2 weeks. As a result, ex-situ seed banking is a viable tool to the long-term conservation of this species as it can assist plant reintroductions to increase wild populations.

\section{References}

1. Guerrant EO, Havens K, Maunder M (2004) Ex situ plant conservation. Island Press Washington DC, USA.

2. Godefroid S, Rivière $S$, Waldren $S$, Boretos N, Eastwood R, et al. (2011) To what extent are threatened European plant species conserved in seed banks? Biol Conserv 144: 1494-1498.

3. Merritt DJ, Dixon KW (2011) Restoration seed banks- A matter of scale. Science 332: 424-425.

4. Smith P, Dickie J, Linington S, Probert R, Way M (2011) Making the case for plant diversity. Seed Sci Res 21: 1-4

5. Roberts EH (1991) Genetic conservation in seed banks. Biol J Linn Soc 43 23-29.

6. Cochrane JA, Crawford AD, Monks LT (2007) The significance of ex situ seed conservation to reintroduction of threatened plants. Austr J Bot 55: 356-361.

7. Rojas-Aréchiga M, Vázquez-Yanes MC (2000) Cactus seed germination: a review. J Arid Environ 44: 85-104.

8. Walters C, Wheeler, LM, Grotenhuis JM (2005) Longevity of seeds stored in a genebank: species characteristics. Seed Sci Res 15: 1-20.

9. Roberts EH (1973) Predicting the storage life of seeds. Seed Sci Tech 1: 499514

10. Andreou M, Delipetrou P, Kadis C, Tsiamis G, Bourtzis K et al. (2011) An integrated approach for the conservation of threatened plants: The case of Arabis kennedyae Brassicaceae Acta Oecol 37: 239-248.

11. Godefroid S, Van de Vyver A, Vanderborght T (2010) Germination capacity and viability of threatened species collections in seed banks. Biodivers Conserv 19 1365-1383.

12. Satterthwaite WH, Holl KD, Hayes GF, Barber AL (2007) Seed banks in plant conservation: Case study of Santa Cruz transplant restoration. Biol Conserv 135: 57-66.

13. Goodman J, Maschinski J, Hughes P, McAuliffe J, Roncal J et al. (2012) Differential Response To Soil Salinity In Endangered Key Tree Cactus: Implications For Survival In A Changing Climate. PLoS One 7: e32528.

14. Ross MS, O'Brien JJ, Ford RG, Zhang K, Morkil A (2009) Disturbance and the rising tide: the challenge of biodiversity management on low-island ecosystems. Frontiers in Ecol Environm 7: 471-478.

15. USFWS (1999) South Florida Multi-species Recovery Plan. Vero Beach, Florida: United States Fish and Wildlife Service.

16. Adams RM, Lima AN (1994) The natural history of the Florida Keys tree cactus, Pilosocereus robinii. Report to USFWS, USA.

17. Ward DB (1979) Rare and endangered biota of Florida: Plants, Volume 5 University Presses of Florida, Gainesville, Florida, USA.

18. Long RW, Lakela O (1971) A flora of tropical Florida: A manual of the seed 
Citation: Salazar A, Maschinski J, Powell D (2013) Ex-Situ Seed Conservation of Endangered Key Tree Cactus (Pilosocereus robinii). J Biodivers Endanger Species 1: 111. doi: 10.4172/2332-2543.1000111

Page 4 of 4

plants and ferns of southern peninsular Florida. University of Miami Press, Coral Gables, Florida, USA

19. Snyder JR, Herndon A, Robertson WB (1990) South Florida Rockland. Ecosystems of Florida, University of Central Florida Press, Orlando, Florida, USA 230-277.

20. FTBG (2008) Conservation Action Plan-Public Version: Pilosocereus robinii. Fairchild Tropical Botanic Garden, Miami, USA.

21. Lima AN, Adams RM (1996) The distribution and Abundance of Pilosocereus robinii (Lemair) Byles and Rowley in the Florida Keys. Bradleya 14: 57-62.

22. USFWS (1986) Key tree-cactus (Cereus robinii) recovery plan. United States Department of the Interior, Fish and Wildlife Service, Southeast Region, Atlanta, Georgia, USA.

23. Goodman J, Walters D, Bradley K, Maschinski J, Salazar A (2012) Seeds of Endangered Harrisia fragrans form persistent soil seed banks and withstand orthodox storage conditions. Haseltonia 18: 85-94.

24. Ranal MA, de Santana DG (2006) How and why to measure the germination process? Revista Brasil Bot 29: 1-11.
25. De Almeida TMH, Andrade ACS, Lopes HM (2009) Brazilian cacti seed germination under different temperature and substrate conditions. Seed Sc Tech 37: 474-479.

26. Mandujano MC, Golubov J, Montaña C (1997) Dormancy and endozoochorous dispersal of Opuntia rastrera in the Southern Chihuahuan Desert. J Arid Environ 36: 259-266

27. Potter RL, Petersen JL, Ueckert DN (1984) Germination responses of Opuntia spp. to temperature, scarification and other seed treatments. Weed Sci 32: 106-110.

28. De la Barrera E, Nobel PS (2003) Physiological ecology of seed germination for the columnar cactus Stenocereus queretaroensis. J Arid Environ 53: 297-306.

29. Silvius KM (1995) Avian consumers of cardón fruits (Stenocereus griseus Cactaceae) on Margarita Island, Venezuela. Biotropica 27: 96-105.

30. Austin D, Krauss P, Jones J, Tatje BE, Nauman CE (1980) Final Report: endangered and Threatened Plant species Survey in Southern Florida. United States Fish and Wildlife Service, Atlanta, Georgia, USA.

31. Vázquez-Yanes C, Rojas-Aréchiga M (1996) Ex situ conservation of tropical rain forest seed: problems and perspectives. Interciencia 21: 293-298. 